\title{
The History of Expropriation in Ethiopian Law
}

\begin{abstract}
Expropriation is a compulsory taking of land by the state for public purpose and upon advance payment of fair compensation. After describing its nature and basic contents, this article attempts to construct the history of expropriation in Ethiopia based on primary and secondary sources. It covers the historical and legislative period of pre-2005 Ethiopia. It is argued in this article that because of lack of urbanism in pre-twentieth century Ethiopia and because of the strong religious ethic of the kings not to abuse their power, there was no much expropriation practice of urban land in Ethiopia before the establishment of Addis Ababa in the late nineteenth century. Expropriation received formal recognition after the 1908 Addis Ababa Land Charter. In all the historical records that are found, there is evidence of payment of compensation upon expropriation of urban land although it might not be conclusive.
\end{abstract}

Daniel Weldegebriel Ambaye *

\section{Key words}

Land, Expropriation, Compensation, History, Ethiopia.

DOI http://dx.doi.org/10.4314/mlr.v7i2.4

\section{Introduction and Method}

Expropriation is a compulsory taking of land ${ }^{1}$ by the state for public purpose activities and upon advance payment of fair compensation. Expropriation is an

* LL.B, MSc, PhD; Assistant Professor of Land Law and Vice Director of the Institute of Land Administration at Bahir Dar University. This article is partly based on the $\mathrm{PhD}$ work of the author.

${ }^{1}$ Land signifies in most countries as including the ground and any fixture thereon such as building and trees and associated rights such as servitude. Under Ethiopian law, property is classified as movable and immovable (Art. 1126 of the Civil Code, hereunder cited as CC.) Land and buildings are considered as immovables (Art. 1130 CC). Ethiopian law follows the French Civil Code Art. 518, which says "land and building are immovable by their nature". The difference is that while the Ethiopian Civil Code is ambiguous as to whether or not building is by default part of the land, the French Civil Code puts a clear stand by stating, under Arts. 552-554, "ownership of the ground involves ownership of what is above and below it." Unless restricted by statutes, the owner of land is considered as owning also the minerals inside the land and the airspace above the land. In Ethiopia, there is no such kind of encompassing provision in the Civil Code. On top of that, presently, as envisaged under Article 40(3) 
inherent power of the state that stems from the very existence of the state, and hence it is argued that the constitutions only give recognition to it instead of authorization. Expropriation assumes different names in different countries such as, compulsory purchase in the United Kingdom (UK), expropriation in Continental Europe and eminent domain in the United States (US). Ethiopia, predominantly follows the Civil Law legal system, and uses the word: expropriation. In this article, the term expropriation is employed with due regard to the possibility of using the other two terminologies as well whenever necessary.

The purpose of this article is to briefly narrate the history of expropriation laws in Ethiopia in a bid to understand the past so that it can serve as a base toward evaluating the unfolding events witnessed so far in Ethiopia. This article is not as such investigating and evaluating the existing expropriation and compensation laws as I have already done that in great lengths elsewhere. ${ }^{2}$ In this introductory part, an attempt is made to describe the methodology employed. Section 1 acquaints readers with the concept of expropriation and its limitations; Section 2 briefly narrates the history of expropriation in pre-1931 Ethiopia; Section 3 deals on the history of expropriation in post-1931 Ethiopia covering the period until 2004; finally Section 4 summarizes the important points. It is, however, to be noted that land confiscation and dispossession that occurred in Ethiopia as a result of feudal expansions during the various eras of Ethiopian emperors is outside the scope of this article. Moreover, the land nationalization measure carried out by the Derg in 1975 is not the subject matter of this article. Focus is rather made to the history of expropriation in Ethiopian law (which is different from nationalization and confiscation).

The article traces back the expropriation law and practice in Ethiopia until the enactment of the current law in 2005. Its purpose is to briefly account its

\& (7) of the FDRE Constitution, ownership of land is vested in the state and the people, while ownership of building is given to the individual. In spite of this duality of ownership of land and building, in this article expropriation of land shall mean also expropriation of other attachments (building and other fixtures thereon) on the ground since the loss of the ground would necessarily be followed by the loss of such proprieties and thus eligible for payment of compensation.

2 Daniel W. Ambaye (2009a) Land Valuation for Expropriation in Ethiopia: Valuation Methods and Adequacy of Compensation, 7th FIG Regional Conference. Hanoi, Vietnam; Daniel W. Ambaye (2009b) Compensation during Expropriation, In Muradu Abdo (ed.), Land Law and Policy in Ethiopia since 1991: Continuities and Changes, Ethiopian Business Law Series, AAU Faculty of Law, Vol. III; Daniel W. Ambaye (2013a) Land Rights and Expropriation in Ethiopia, Doctoral Dissertation, KTH, Stockholm; Daniel W. Ambaye (2013b) Compensation for expropriation in Ethiopia and the UK: Comparative Analysis, Bahir Dar University Journal of Law, Vol.3, No. 2, pp. 279295. 
practice rather than delving into detailed history of tenure or property right. The method followed is therefore historical research. Historical research is an examination of elements from history. From a social science perspective, history is an account of some past event or a series of events. Historical research, then, is a method for discovering, from records and accounts, what happened during some past period. ${ }^{3}$

This chronology of historical events describes important past events, people, developments, and the like. It also provides the reader with a sense of which things or events came before others. Historical research thus involves a process that examines events or combinations of events in order to uncover accounts of what happened in the past. This provides access to a broader understanding of human behavior and thoughts than would be possible if we were trapped in the static isolation of our own time. Therefore, understanding the historical nature of phenomena, events, people, agencies, and even institutions is important. One cannot fully evaluate or appreciate advances made in knowledge, policy, science, or technology without some understanding of the circumstances within which these developments occurred. ${ }^{4}$

The sources of data used by this article are primary and secondary data. Primary sources are original artifacts, documents, and items related to the direct outcome of an event or an experience. ${ }^{5}$ They may include documents, photographs, recordings, diaries, journals, life histories, drawings, mementos, or other relics. Secondary sources involve the oral or written testimony of people not immediately present at the time of a given event. They are documents written or objects created by others that relate to a specific research question or area of research interest. Secondary sources may include textbooks, encyclopedias, oral histories of individuals or a group, journal articles, newspaper stories, and even obituary notices. ${ }^{6}$

This article relies on a desk review of primary and secondary sources to describe the nature of expropriation and to trace its historical application in Ethiopia. Constitutions, codes of law and proclamations which are considered as primary sources are consulted to trace the history of expropriation. Moreover, secondary sources such as books, journals and other related documents have been reviewed to analyze the definition, nature and historical genesis of expropriation.

\footnotetext{
${ }^{3}$ Marshall, C. and Rossman, G. B. (1999). Designing Qualitative Research, Thousand Oaks, CA: Sage.

${ }^{4}$ Salkind N.J. (2008). Exploring Research, Englewood Cliffs, NJ: Prentice Hall.

${ }_{6}^{5}$ Id., p. 162.

${ }^{6}$ Brink, P. J. and Wood, M. J. (1989). Advanced Design in Nursing Research. Newbury Park, CA: Sage.
} 


\section{Conceptualizing Expropriation}

Expropriation assumes different names in different legal systems. As stated in the introduction, it is known by the name "Eminent Domain" in the United States, "Compulsory Purchase" in the United Kingdom and "Expropriation" in continental Europe. ${ }^{7}$ Ethiopia uses the term "expropriation". This article mainly uses the word 'expropriation' and also uses 'eminent domain' and 'compulsory purchase' depending upon the context or setting in which the concept is discussed.

Eminent domain can be defined as "the power to take private property for public use by the state, municipalities, and private persons or corporation authorized to exercise functions of public character." Bouvier defines the term as "The superior right of property subsisting in sovereignty by which private property may in certain cases be taken or its use controlled for the public benefit, without regard to the wishes of the owner." Eminent domain is also defined as "the power of the sovereign to take property for 'public use' without the owner's consent." 10 In all the definitions, eminent domain or expropriation is described as the power of the sovereign state or agencies delegated by it to compulsorily take land for public use purposes. What is missing from the definitions is the "compensation" element. Actually, when we look into the definition of eminent domain in earlier decisions of American courts or State Constitutions, compensation as an essential constituent of its meaning came later. $^{11}$

${ }^{7}$ A court in Louisiana, a state in the USA that follows a Civil Law (continental) legal system, once declared that the term 'expropriation' used in our statutes is practically synonymous with the term "eminent domain." See (Tennessee Gas Transmission Co. v. Violet Trapping Co., 200 So. 2d 428 (1967); In Louisiana, taking land for public use by eminent domain is called by the name "expropriation." See WEST'S LAS C.C. 2626; Both FAO and FIG study reports used the three of them interchangeably (FAO 2008. Compulsory Acquisition of Land and Compensation. FAO Land Tenure Studies 10. Rome: Food and Agriculture Organization of the United Nations; Viitanen, K., Falkenbach, H. \& Nuuja, K. (2010). Compulsory Purchase and Compensation Recommendations for Good Practice. FIG Policy Statement. Helsinki International Federation of Surveyors.

${ }^{8}$ Black, H. C.(1990). Black's Law Dictionary. 6th ed. St, Paul, Minn.: West Group.

${ }^{9}$ Bouvier, J. (1984). Bouvier's Law Dictionary. 4th ed.: William S Hein \& Co.

${ }^{10}$ Nichols, P. (2007) 1 Nichols on Eminent Domain Matthew Bender \& Company, Inc, $\S 1.1$

${ }^{11}$ Id., § 1.11. Example in Jones v. Walker, 13 F. Cas. 1059, 2 Paine 688 (Va. Cir. Ct. 1800), "eminent domain" is defined as: "The right of society, or of the sovereign, to dispose, in case of necessity, and for the public safety, of all the wealth contained in the state." Looking into the State Constitutions of the early States in the USA, one can observe that in their eminent domain clauses, "most state constitutions omitted 
In some modern definitions of the terminology, the element of compensation is still left out. For example, FAO's definition of the term could be a good example: "Compulsory acquisition is the power of government to acquire private rights in land without the willing consent of its owner or occupant in order to benefit society."12 It must be admitted that despite the logical accuracy of the foregoing definition and despite the fact that the payment of compensation is not an essential element of the meaning of eminent domain, compensation is an essential element of the valid exercise of such power. The absence of an explicit provision requiring compensation for the taking of property should not be seen as evidence of a rejection of the compensation principle. On the contrary, compensation was a well established feature of takings by eminent domain in most countries, as we shall see in the next section.

In Ethiopia, the first systematic definition for the concept was given in the Ethiopian Civil Code enacted in 1960. The Code, under Article 1460, provides:

Expropriation proceedings are proceedings whereby the competent authorities compel an owner to surrender the ownership of an immovable required by such authorities for public purposes. ${ }^{13}$

In this definition, the idea of the taking of private land by the state or authorities without the consent of the owner for public purpose is clearly envisaged. The phrase "expropriation proceeding" is employed here instead of the word "expropriation" because of a translation error from the original French version. ${ }^{14}$ It is said that the original French version has defined the term as follows: "expropriation is a procedure by which the administration obliges an owner to surrender to it the ownership of an immovable which it needs for the purpose of public utility." 15 And yet, like the above definitions, the rule noticeably fails to include the element of compensation in its definition.

any specific mention of a right to compensation." See Harrington, M. P. (2001). "Public Use" and the Original Understanding of the So-Called "Taking" Clause. Hastings Law Review, 53, p. 1276; Ratovil, R. \& Frank, J. Harrison, J. (1954). Eminent Domain-Policy and Concept. Cal. L. Rev., 42, 596-652, p. 596; Grant, J. A. C. (1930). The "Higher Law" Background of the Law of Eminent Domain. Wis. L. Rev., 6, p. 70. According to Grant, only Vermont and Massachusetts required compensation during expropriation.

${ }^{12}$ FAO, supra note $7, \S 2.1$

${ }^{13}$ Article 1460 of the Civil Code.

${ }^{14}$ Getachew Desta, (1975). Expropriation: Law and Practice, Unpublished senior thesis at the Faculty of Law of Addis Ababa University, Addis Ababa, p. 6. The original draft of the Civil Code was prepared by the French Comparative Lawyer, René David, in French, and then translated to English and from that to Amharic. There are many translation errors throughout the Code, Art, 1460 being one of them.

${ }^{15}$ Ibid. 
Without undermining the above definition, the following one may be considered as a working definition in discussing the details, as it is more comprehensive. This definition elaborates the concept of eminent domain as follows:

$\ldots$ it is the right of the nation or state, or of those to whom the power has been lawfully delegated, to condemn private property for public use, and to appropriate the ownership and possession of such property without the owner's consent on paying the owner a due compensation to be ascertained according to law. ${ }^{16}$

This definition seems more complete, since it includes all the basic elements. First of all, expropriation or eminent domain is a right that is exercised by the state itself or its sub-branches such as municipality and other public or private companies and persons legally authorized by the state/legislature. Sustainable development requires governments to provide public facilities and infrastructure that ensure safety and security, health and welfare, social and economic enhancement, and protection and restoration of the natural environment. ${ }^{17} \mathrm{An}$ early step in the process of providing such facilities and infrastructure is the acquisition of appropriate land. Government may use alternative land acquisition mechanisms such as purchase, to secure land for public purpose activities. But, it is impossible to rely totally on the land market as individuals may create a holdout on the projects or the land required may involve the interest of many owners that warrants the exercise of expropriation power. As we shall see in the next section, the expropriation power is inherent in the state power.

The second element is that the state or the organs authorized to take such lands must follow some procedure. In the US, it is known as "condemnation proceeding" while in other countries, mainly European, it is referred to as an "expropriation procedure." The main idea is that the state must ensure due process of law before appropriating the property. In the US, courts are usually involved in the proceeding, and the process consists of two phases: proceedings that relate to the existence of "public use" that justifies the taking, and proceedings to set the amount of compensation to be paid for the property taken. ${ }^{18}$ The state or an authorized organ shall first petition the court for appropriation of the property and the owner will be given the right to be heard and to negotiate on the amount of compensation, and finally, the court must

\footnotetext{
${ }^{16}$ Amendola, F. C. \& et.al. (eds.) (2006). Eminent Domain Corpus Juris Secondum. 29A C.J.S: Thomson West, $\S 2$ (hereinafter C.J.S.).

${ }^{17}$ FAO, supra note 7, p. 1 .

18 West's Encyclopedia of American Law (2005). In: J. Lehman. \& et al (eds.) Eminent Domain. Vol.4, 2nd ed. San Francisco, London and Munich: Thomson Gale, p. 125.
} 
approve it. In other countries, expropriation procedure is either purely administrative procedure or a hybrid of court and administrative decisions. ${ }^{19}$ This procedure avoids arbitrary takings of land by the state without fair compensation.

The third point worth discussing is the issue of "public use." The doctrine of expropriation stands in opposition to the right of private property. Thus, expropriation requires finding a balance between the public need for land on the one hand, and the provision of land tenure security and the protection of private property rights on the other hand. In seeking this balance, the expropriation principle includes the requirement of "public interest" as one limitation on the state power of expropriation. This limitation or requirement is known by different names in different countries, such as public use, public benefit, public good, public interest, public purpose or public welfare. ${ }^{20}$ The idea is that, there may be exceptional times and places in which the very foundations of public welfare cannot be laid without requiring concessions from individuals to give up their private property in the interest of the common good.

The appropriation or taking, mentioned in the definition, is the fourth important aspect or stage in expropriation procedure. There are several types of appropriation which can occur through expropriation. The major types include total appropriation, partial appropriation, temporary appropriation, easement and right of way. Under the Ethiopian Civil Code, the defunct expropriation rules show that expropriation may be used either to acquire or terminate rights in rem such as servitude, usufruct or lease. ${ }^{21}$ Expropriation differs from such similar concepts like police power (termed in the USA) or regulations that limit the use right of the property due to health, public safety, etc., in that it involves the loss of the core constituent right of disposal. In the latter case, what the owner loses is some part of his use right over his property, while in the case of expropriation he loses the entire or part of the property.

The fifth point embodied in the definition is the absence of consent on the part of the owner. The power of eminent domain/expropriation is a sovereign power of the state to take private land without the consent of the owner. What makes expropriation different from other consensual types of land acquisition mechanisms is the complete absence of consent on the part of the property owner. It is true that many public and private organs do also collect land through purchase and similar transactions which are based on the willingness of the person. But, it may not be realistic to totally rely on the good will of the owner

\footnotetext{
${ }^{19}$ See details for example in Kitay, M. G. (1985). Land Acquisition in Developing Countries: Policies and Procedures of the Public Sector, Boston, Oelgeschlager, Gunn \& Hain, Publishers, Inc.

${ }^{20}$ FAO, supra note 7, p. 10.

${ }^{21}$ See Ethiopian Civil Code, Articles 1460-1461.
} 
to get land for different reasons. The state, hence, resorts to such coercive proceedings for two main reasons: first, owners may create a holdout on the public development activities either by totally refusing the sale of the land at any given price or by requesting unrealistically higher prices for the sale of their properties; and second, public development projects which demand long and continuous land holdings involve the interest of many owners and it may be difficult to reach agreement with all owners. In both scenarios, owners try to impede the public welfare that could be attained by using their land.

The last principle included in the definition is the obligation of payment of fair compensation. This principle is the most important guarantee to individual owners on their lawful possessions. All major legal systems and constitutions include this concept as a guarantee to the owner and as a limitation of the power of government. The just compensation requirement demands that the state reimburse the owner the value of the property interest taken and place the latter in as good a pecuniary position as if the property had not been taken. The assessment of compensation is extremely complicated, and different countries incorporate different valuation methods within their expropriation legislation to reach the market value. ${ }^{22}$ Nevertheless, the existence of compensation makes expropriation tolerable and differentiates it from other government actions, such as confiscation, nationalization, and eviction, because the latter three are devoid of the state obligation to compensate for the taking.

\section{Brief History of Expropriation in Ethiopia: Pre-1931}

It is difficult to trace the historical genesis and application of expropriation in pre-twentieth century of Ethiopian history because either it was intentionally neglected by historians as land was not extensively used for public works or because of the deep-rooted assumption of ownership of land by the king. Although there is ample evidence on the nature and type of land use rights over a long period of Ethiopian history, expropriation is mentioned very rarely. We find some allusions here and there that might give us a clue on the existence and practice of expropriation; and yet, it is not conclusive to say that it existed in full practice before the enactment of the 1908 Addis Ababa Land Charter. An attempt is made to construct its history and genesis from the scant records that we found. For the sake of convenience, this section is divided into pre-1931 Constitution and post-1931.

As mentioned by different writers, national or foreign travelers, the powers of the Ethiopian monarchs had been absolute. ${ }^{23}$ Therefore, we could assume that

22 See generally Kitay, supra note 19.

${ }^{23}$ During his stay in Ethiopia in the $16^{\text {th }}$ century, the Portuguese priest, Francisco Alvarez, testified that the power of the king was absolute (Alvarez, F. (1970) 
the emperors could take land that belonged to any person, at their pleasure, although this may not have happened frequently for two main reasons: first, until the early twentieth century, there was no significant economic development in the country that warranted the taking of land for public construction activities; and second, the emperors who mostly relied on the teaching of the Christian morality would not resort to cruel measures of land confiscation unless the person commits serious crimes. Both of these assertions are backed by some evidence presented hereunder.

\subsection{Urbanism}

In Ethiopia, the power to take land for public purpose did not become a matter of great concern until the early twentieth century. Until this point in history, Ethiopia's need for public works was rather limited. The country's economy was predominantly agricultural, and urbanization was totally unknown. ${ }^{24}$

(Originally translated by John Stanley in 1881). Narrative of the Portuguese Embassy to Abyssinia During the Years 1520-1527, London, The Hakluyt Society). A hundred years later Almeida (a Jesuit priest) said "the Emperor confiscates and grants all the lands as and to whom he chooses"; (see Pankhurst, R (1966) State and Land in Ethiopian History, Addis Ababa, The Institute of Ethiopian Studies and the Faculty of Law, Haile Sellasie I University, p.121;) James Bruce a $17^{\text {th }}$ century Scottish traveler to Ethiopia has also declared that "all the land is the king's; he gives to whom he pleases during pleasure and resumes it when it is his will; but the crown makes no violent use of its power in that respect."(Paul, J. C. N. \& Clapham, C.(1972), Ethiopian Constitutional Development I, a Source Book, Addis Ababa, Haile Sellassie I University and Oxford University Press, p. 290); William. C Harris who lived in Shoa also noted that "The lives and the lands of every subject of Shoa belong de jure to Sahela Selassie, and of their persons and worldly substance he is absolute master" (Harris, W.C (1884) Highlands of Ethiopia, Longman, Brown, Green and Longmans, London, p. 167); An Ethiopian writer and Minister during the Imperial period also noted: "the Ethiopian Emperor has an uncontested and boundless power over the territories he rules. He is both the temporal and spiritual ruler" (Mahteme Sellasie, infra note 48).

${ }^{24}$ This is true with due regard to the existence of two previous capitals of the realm, namely Axum (100 BC-800 AD) and Gonder (17 -18 Century). The evidence that cities were absent in Ethiopia was conclusive after European travelers reached the high plateau during and following the fifteenth century. They commented not only upon the tent encampments, but also upon the total lack of urbanism in Ethiopia. One such commentary is Francisco Alvarez's narrative of the Portuguese Embassy to Ethiopia in 1520 states: 'In all the country there is no town which exceeds 1,600 households, and of these there are few, and there are no walled towns or castles, but villages without number.' (The estimate of houses would put the population of the largest town between 8,000 and 10,000.) Accounts written after Alvarez's time were not anywhere nearly so generous with their estimates of the population and number of towns. Jerome Lobo, visiting Ethiopia during the early 1600s, noted that the 
Throughout most of its history, Middle Age Ethiopia remained a land of small villages and isolated homesteads; ${ }^{25}$ hence, there were fewer motives for the leaders of the time to take land for public works. Modern urbanization started only with the establishment of the present capital, Addis Ababa in 1886. Although modern road construction works started on a small scale and for military purpose earlier during the middle of the nineteenth century, it was intensified only after the establishment of the capital. ${ }^{26}$ Therefore, in the absence of historical records to that effect, it can be concluded that because of absence of urbanism and thereby a need for infrastructure, the level of expropriation was minimal.

\subsection{Less abuse of power}

Even if the power of the kings was said to be indisputable over the people and their properties, one needs to be cautious regarding whether this absolute power was also extended to all types of land rights. A glimpse into the Ethiopian history of property rights vis-à-vis the power of the sovereign kings shows that land which was said to be controlled by the king was transferred in the form of rist and gult rights to individuals and the church. While gult right was a fief right that was given to the nobility and empowered them with privileges of

Ethiopians did not have cities since they lived in tents and in cottages only rarely built of stone. Visiting Ethiopia between 1624 and 1633, Manoel de Almeida said: 'Apart from the Emperor's camp there is no settlement in the whole empire that deserves the name of city, or even of town. They are all villages, some larger, some smaller, but such that no other name suits them. In the seventeenth century, a German scholar, Job Ludolf, wrote: 'Besides Aksum, there are no Cities in Habessinia, and but few towns.... The Habessines wonder to hear of so many great Cities among us ... [and] ... the Habessines choose rather to live after the manner of Villagers... .' Ludolf believed that there had been a general regression in the technology of construction after the Ethiopian monarchs left Aksum (Gamst, F. C. (1970). Peasantries and Elites without Urbanism: The Civilization of Ethiopia. Comparative Studies in Society and History, 12, 373-392, p. 379).

${ }^{25}$ Pankhurst, R. (1990). A Social History of Ethiopia, Addis Ababa, Institute of Ethiopian Studies, Addis Ababa University, p. 275.

${ }^{26}$ As detailed by Richard Pankhurst, modern road building began during the reign of Emperor Tewodros II (1855-1868) with the intent of creating easy and rapid movement for his military and cannons. Assisted by foreigners he was able to link his capital, Debre Tabor, with three main routes to Gonder, Gojam and Gafat. To break Tewodros, the British had also resorted to road construction by starting from the sea. But quality and modern roads started to emerge with the establishment of Addis Ababa by Emperor Menelik II. The early half of the twentieth century was thus a time in Ethiopia which can be portrayed as a time of public works development and extensive use of expropriation. (see Pankhurst, R. (1968). Economic History of Ethiopia 1800-1935, Addis Ababa, Haile Sellassie I University Press. p. 284-289). 
administration, tribute collection and adjudication over the peasant settled on the land, rist right confers actual use right to the farming population. This means gult right was like an office or position that required imperial blessing for its continuity or inheritance. On the other hand, rist right was a property right that could be mostly inherited among kin members. ${ }^{27}$

Historical records show that the indisputable power of kings was working in relation to gult rights. Kings used to take and give gult rights to the nobility at pleasure. On the other hand it is claimed that rist right of individuals was sacred and secure, in that even kings could not arbitrarily take it at whim. ${ }^{28}$ There was less abuse of power when it comes to rist rights because of religious and moral grounds. As James Bruce, the eighteenth century Scottish traveler to Ethiopia, underlined, although the monarch had this absolute right over the land and the subjects in respect of taking, the emperor "makes no violent use of its power in that respect." ${ }^{29}$ A similar conclusion was reached by the nineteenth century British traveler to central Ethiopia who after emphasizing the arbitrary power of the King of Shoa, noted that: "[v]iolent use is not often made of this arbitrary power, and it is rarely resorted to, except in cases of high treason or of offences against the state, which, in place of capital punishment, are visited by confiscation of property, with imprisonment for life." 30

According to the evidence that is found, it is said that King Lalibella of the Zagwe Dynasty (early $13^{\text {th }}$ century) ${ }^{31}$ had made payments for the land he used to

${ }^{27}$ For details on the nature of gult and rist rights see, Hoben, A. (1973), Land Tenure Among the Amhara of Ethiopia: The Dynamics of Cognatic Descent, Chicago, University of Chicago Press.

${ }^{28}$ See for example, Markakis, J. (2006). Ethiopia: Anatomy of a Traditional Polity, Addis Ababa, Shama Books, p. 103; see also Jemma who, based on the claims of different historians, argued that rist was perceived as "sacred hereditary property". Accordingly, whoever have had the rights to the rist land was considered to be a ristegna. A ristegna had almost absolute or an unchallengable control, use and inheritance rights over his or her possession. As far as political authorities, including the emporer or landlord interventions were concerned, there was no tenure insecurity or fear of being evicted from the rist land (Hussein Jemma (2004) The Politics of Land Tenure in Ethiopian History: Experience from the South, paper presented for the XI World Congress of Rural Sociology, Trondheim, Norway.) This was generally attributed to the deep-rooted protection provided by the ruling class to rist rights mainly for fear of God's presecution.

${ }^{29}$ Paul and Clapham, supra note 23, p. 290.

${ }^{30}$ Harrison, supra note 23, p. 167.

${ }^{31}$ The Zagwe dynasty ruled the country from approximately 1137-1270. Zagwe (in the ancient Geez language) means "that of the Agew" in reference to the Agew People that constituted its ruling class. King Lalibella (later Saint Lalibella) is the most celebrated king of this dynasty who built eleven rock-hewn monolithic churches 
construct his well known churches. The hagiographer of the King compliments him for paying for the land on which he built his churches. "He attributes this to the king's special sense of piety and saintliness and asks a rhetorical question to demonstrate the traditional power of the monarch in the distribution of land: 'who would have forbidden the king if he had decided to take the land' (without compensation)?"32

Another evidence which is associated with Christian morality is the rule that was incorporated into the $15^{\text {th }}$ Century law of the country, Fiteha Negest (The Laws of the Kings). There is a provision embodied in the Fiteha Negest that was influenced by the Biblical story of King Ahab. ${ }^{33}$ By referring to the biblical story, the Fitha Negest provides: "Do not take wealth of any one by violence, and do not buy from him by force; neither openly nor by trick, in order not to be afflicted by God in this world and in the future..."34

Of course, this rule by itself is not as such telling about expropriation, but what is important is the message that it incorporates. The message here is that nobody (a person or a king) should take the property of another person by violence (such as theft and robbery) or buy by force (such as compulsory purchase). One may argue that this provision does not give the power of expropriation to the sovereign for it clearly forbids the taking of land without the consent of the owner. But, the implication is that in the event of pressing public necessity, the king would have no choice but to expropriate the land, and to rectify this wrong (transgressing the Fiteha Negest), he would make a recompense in kind or in cash to those who lost their property.

from blocks of solid rock to be known as "New Jerusalem." The Churches of Lalibella are now in the list of the UNESCO World Heritage sites.

32 Tadesse Tamirat. (1972). Church and State in Ethiopia, 1270-1527, Oxford, Clarendon Pres, p.98.

${ }^{33}$ Holy Bible. King James Version, 1 Kings 21:1-16. According to the Bible, Israel's King Ahab desired a vineyard owned by Naboth the Jezreelite to grow herbs on it. He offered Naboth his choice of either a new vineyard or "the worth of it in money." When Naboth refused to sell, Jezebel, Ahab's wife, conspired with others to put Naboth to death. As a result God punished King Ahab and his family by death.

${ }^{34}$ Fitha Negest (Amharic and Geez Version). Addis Ababa: Tesfa-Gebre-Sellassie Printing Press, Article 1544. The Fitha Negest (Law of the Kings) is a sophisticated compilation of legal prescriptions concerning both religious and secular matters written in approximately the $13^{\text {th }}$ century in Egypt as a guide to Christian population living within the Moslem society. Originally written in Arabic, and incorporating laws from Old and New testament, Roman law, and some Moslem principles and the proceedings of the early councils of Nicaea and Antioch, it is believed that it was translated to Geez (official state and church language of ancient Ethiopia) in the $15^{\text {th }}$ century, during the reign of Emperor Zera Yaqob (1434-1468) and had been serving as binding law in the imperial court. 
When Emperor Fasiladas (1632-1667) established the then capital city of Gonder, he must have taken lots of land from farmers, or he must have built it on barren hilltops. There are extensive records that show the private ownership and free transaction of land in the Gonderine period..$^{35}$ In other words, land was held in private hands during that period. But, there is nothing important that is said about the expropriation of land in that era. Yet, we can assume that the later monarchs must have taken land either by purchase or expropriation from private owners for the construction of churches, royal castles, streets and market places during the subsequent century and half, following the establishment of Gonder by Fasiladas.

The church was a holder of large tracts of land property throughout the history of Ethiopia. ${ }^{36}$ Emperors of different eras made the grants to churches and monasteries so that the latter would be supported from the income. However, sometimes, this smooth relationship between the church and the palace encountered difficulties, which resulted in the expropriation of church lands. For example, as a result of the clash he had with the Church on religious matters, Emperor Susneyos (1607-1632) is said to have seized a substantial part of land belonging to the monastery of Debre Bizen. ${ }^{37}$ In a later period, extensive land which caused tension was expropriated by Ras Michael Sehul of Tigre. According to James Bruce's records, as a result of the friction that Michael had with the Church authorities, a royal proclamation was issued at Gonder in 1771 ordering that "all lands and villages, which are new, or have been given to the Abuna by the king, shall revert to the king's own use, and be subject to the government, or the Cantiba [mayor] of Dembea, or such officers as the king shall after appoint in the provinces where they are situated." ${ }^{38}$ In both cases, church land was taken or reverted to the kings' hands without compensation. Besides, there is no evidence which shows that the land was taken for the common good of society; rather it was taken because of power struggle between the monarchs and the Church.

We find a similar story, in a later period, when Emperor Tewodros II (18551868) wanted to reform the land tenure and the Church itself. Among others, he ventured to reduce much of the Church's land and transfer it to landless

${ }^{35}$ For example see Crummey, D. (2000). Land and Society in the Christian Kingdom of Ethiopia: From the Thirteenth to the Twentieth Century, USA, University of Illinios Press, p.183; Pankhurst: 1966, supra note 23, p. 52.

${ }^{36}$ See for example Daniel:2013a, supra note 2, pp. 48-50.

${ }^{37}$ Pankhurst: 1990, supra note 25, p. 33.

${ }^{38}$ Bruce, J. (1790). Travels to Discover the Source of the Nile in the Years 1768, 1769, 1770, 1771, 1772 \& 1773, Edinburgh, R G. G. J. and J. Robinson, Paternoster-Row, Vol. 4, Book 7, Chap. 3: 78 (accessible on line). 
tenants $^{39}$ and to his soldiers who used to live by plundering and raiding peasants. ${ }^{40}$ The Emperor was complaining on the magnitude of Church land as compared to his own which was intended to be allotted to the soldiers. The clergy resisted the Emperor's plans but as the contemporary missionary, Henry Blanc said, "Theodore could not tolerate any power in the state but his own. He had fought hard to be the supreme ruler of Abyssinia ... and when he thought the occasion favorable to do away entirely with his power and influence, he confiscated all the Church lands and revenues."41 His ultimate aim was to transfer the Church land to landless peasants and soldiers for better use, as salary, and to make it more productive. ${ }^{42}$ Although his attempt was not successful, ${ }^{43}$ this, at least, may be considered as a good example of expropriation, if the establishment of modern salaried military (defense) could be considered as an act done in the interest of the public.

${ }^{39}$ Tewodros passed a proclamation in 1856 which seems to institute property in Shoa. It decreed that land should belong to those whose fathers had already held it as fiefs and that persons without any such claim should look to the Emperor as their father (Pankhurst: 1968, supra note 26, p. 142.)

${ }^{40}$ Caulk, R. A. (1978). Armies as Preditors: Soldiers and Peasants in Ethiopia c. 18501935. The International Journal of African Historical Studies, 11, 457-493. For centuries soldiers used to get food from peasants either by force or through voluntary provision.

${ }^{41}$ Blanc, H. (2007) (Original 1868). A Narrative of Captivity in Abyssinia: With Some Account of the Late Emperor Theodore, His Country and People, Harvard, Harvard University, p. 150; See also Pankhurst: 1968, supra note 26, p. 143. All Church land was confiscated and the number of priests was limited to five to seven. The Emperor disliked monks and above all dabtaras, complaining that they "wore turbans on their heads and neither fought nor paid taxes", preferring to "live in cities with prostitutes and other people's wives." (Ibid.)

${ }^{42}$ Pankhurst: 1966, supra note 23, p. 95; Crummey, D. (1969). Tewodros as Reformer and Modernizer The Journal of African History, 10, 457-469. Crummey argued (at page 468) that Church lands were making no real contribution to the national economy since the larger part of them were uncultivated, partly through the indolence of the clergy, partly through the disincentive which they gave to any peasants who might want to till them by means of high taxes.

${ }^{43}$ With a clash that he had with Great Britain, the Emperor shot himself before the English put hand on him. And the opposition from the priesthood contributed significantly to his fall for they were prime movers and instigators of various regional rebellions made against him. The rebellions debilitated his power which created an opportunity for the British to win easily. After the death of Tewodros, leaders of different regions and by and large the succeeding Emperor, Yohannes IV, declared at once the restoration of Church lands to their former owners. (Pankhurst: 1968, supra note 26, p. 143.) 
The sovereign's right in respect to the land in Shoa (central Ethiopia) was also similar, if not greater than that of the northern Ethiopia. In a similar fashion as noted above, it has been said that in Shoa "all the best portion of the soil pertain to his Majesty, and all the life as well as the property of every subject is at his sole and absolute disposal." 44 Yet, some evidence from this part of Ethiopia shows that expropriation to meet royal needs seems to have been accompanied by the provision of alternative land for the dispossessed. Richard Pankhurst, citing a contemporary English traveler of the time, Charles Johnston, relates that when Sahel Sellasssie, King of Shoa (1813-1847) erected his palace at Ankobar, many people had been evicted from their land. The Englishman was greatly interested in the matter and made careful investigation about the fate of the peasants. He particularly wanted to know whether "any injustice had marked this course." His informants all agreed that ample compensation had been given by the king to the peasants. ${ }^{45}$

Ethiopia witnessed considerable amount of road construction after Emperor Menelik II came to the throne in 1889. Many and impressive amount of roads were constructed in the city of Addis Ababa during his reign. ${ }^{46}$ Another important accomplishment of his period was the construction of a $781 \mathrm{~km}$ railway from Djibouti to Addis Ababa and the establishment of new towns along the new railroad. In 1894, the railway company was established and the Emperor was asked to "grant to the company a continuous stretch of territory along the entire length of the line." 47 The amount of land, according to Section Eleven of the concession contract, was to be 1000 meters in width. But, a 1908 revised contract under Section Four indicates that the width of the land through which the railway pases would be 1000 meters from Djibouti to Dire Dawa, 200 meters from Dire Dawa to Awash, and 50 meters from Awash to Addis Ababa. ${ }^{48}$ This shows the amount of land given decreased as the line came from the lowland desert to the highland populous areas of the country.

Although there is information on the sale and purchase of land in those newly established towns, such as Dire Dawa, whether the land utilized for the railways construction was acquired through purchase or expropriation is not known. Nevertheless, the assumption is that since the eastern part of the country in

${ }^{44}$ Harris, supra note 23, p. 279.

${ }^{45}$ Pankhurst: 1968, supra note 26, p. 140; See also Pankhurst:1966, supra note 23, p. 81 ;

${ }^{46}$ For details see Pankhurst, R. (1961). Menelik and the Foundation of Addis Ababa. The Journal of African History, 2, 103-117.

${ }^{47}$ Id., p. 168.

${ }^{48}$ See the full versions of the 1893 and 1908 railroad construction concessions as reproduced in Mahteme-Sellassie, W. M. (1970). Zekre Neger, Addis Ababa, 2nd ed., pp. 440-449. The original agreement dictates that the first phase was to be built from Djibouti to Harar, and the second from Harar to Enteto. 
which most of the railways are located was mostly a desert inhabited by the Afar pastoralists, the land might not have been purchased or expropriated. But, in towns and in the central highland plateaus, where the land was populated, the Emperor must have expropriated land for such purpose. Yet, there is no available information whether or not compensation was paid at that time.

Nonetheless, there is relevant information from the same period that seems to enlighten us on the tradition of the time concerning expropriation procedures and compensation. This interesting story was told by Robert Skinner, the head of American Mission in Ethiopia during the reign of Menelik II. He noted that in 1903, a year before the road between Dire Dawa and Harar was projected, it was necessary to take the land required for the construction of the road. The local peasants who lost their land waited upon the governor, Ras Mekonnen ${ }^{49}$, and complained saying that their farms would be ruined and as a result they could not accept a price offered for their land. Surprised, the Ras asked, "But it is fair price, is it not?" and the peasants answered: "It is not the price we complain of, most gracious lord; we don't want our farms destroyed." The Ras thereupon ordered them out of his presence, saying, that there was but one Governor of Harar, and that he alone would say what might or might not be done. The road was constructed... and when it was all over, the Ras called the peasants before him, and telling them that he had been compelled to exert his authority in order to demonstrate his supremacy, he was now prepared voluntarily to pay them twice the value of their property, thus showing them that their Governor could be generous as well as just. ${ }^{50}$

This story is interesting in the sense that the concept of expropriation is fully explained by it. Road construction is a work considered as a public good in expropriation. We also see the absence of consent on the part of the peasants to surrender their land; it was rather compulsorily taken. We even see the compensation paid to the farmers in lieu of their lost land. The other important assumption that we may gather from it is that there was the tradition of payment of compensation in the event of expropriation. The Governor of Harar was a trusted General and a close counsel of the Emperor, and hence what he had done at that time must be based on tradition or the acts of the Emperor himself. Taking into consideration the fact that both the railroad and the gravel road were constructed at the same period, and the fact that both cousins (the Emperor and the Governor) shared the same principles and beliefs, we can safely conclude

${ }^{49}$ Ras Mekonnen was a cousin of the Emperor and a father of Teferi Mekonnon, the future Emperor Haile Sellassie. He was a trusted General and Governor of the eastern city of Harar and the surrounding Somali areas. Ras means literally "head" and it was the highest military title given by that time.

${ }^{50}$ Pankhurst:1966, cited supra note 23, p. 169; Pankhurst: 1968, supra note 26, p. 289. 
that land owners who lost their property to the construction of the EthioDjubouti railroad must have received compensation.

One may also look into the historical developments of the time concerning property rights, all of which reinforce the above assertion, that the King must have been paying compensation. Emperor Menelik II was a leader who not only allowed the introduction of modern technology, but also established a cabinet of ministers to run the state. The Emperor in consultation with his ministers passed a series of edicts, among others, concerning land property. For example, his royal chronicler tells us that in January 1891, Menelik, after consulting the Fitha Negest, passed an edict concerning land found in Shoa (from Wayt to Awash). It shortly says that "no rist land shall be expropriated from the owner irrespective of his crimes; let his cattle be taken as penalty". ${ }^{51}$ A general decree containing a similar intention was adopted by Menelik's council of ministers in 1908, which said that "...no one should be evicted from his rist land except those escapee killers" and persons guilty of treason. ${ }^{52}$ Menelik's daughter, Empress Zewditu, had also passed similar edict in 1928 which guarantees protection of rist land. "The edict gave legal confirmation to the ownership right of all rist-holders, guaranteeing against expropriation for whatever crimes committed." 53 These series of edicts substantiate the principle and commitment of Emperor Menelik and his descendants to protect and guarantee private ownership of land in Ethiopia.

Menelik's final commitment to the protection of private property came in 1908 when he decreed the Addis Ababa City Land Charter that affirmed, once again, the protection given to private ownership of urban lands. It is in this charter, for the first time, that we find the principle of expropriation clearly set as an independent principle. Articles 25 and 27 of this legislation ${ }^{54}$ are of particular significance to the topic under discussion:

\section{Article 25}

For the safety and security of the city, private owners might be compelled to sell their land together with a house, if any, to the government. The amount of compensation payable shall be determined by government experts.

${ }^{51}$ Tsehafe Tezaz Gebre Sellasie (1959 EC). Tarik Zemen ze Dagmawi Menelik Nuguse Negest Ityopia (History of the Lives and Times of Menelik II King of Kings of Ethiopia), Addis Ababa, Artistic Ltd., p. 179.

${ }^{52}$ Id. pp. 334-336.

${ }^{53}$ Bahru Zewde (2008). Economic Origins of the Absolutist State in Ethiopia (19161935). In: Zewde, B. (ed.) Society, State and History: Selected Essays. Addis Ababa: Addis Ababa University Press, p. 105.

${ }^{54}$ The 1908 Minelik's Addis Ababa Land Charter, as reproduced in Mahteme-Sellassie, supra note 48, p.170; with slight difference in translation, see also Pankhurst: 1966, supra note 23, p. 158. 
Article 27

If there is building on the land, the government shall pay the amount agreed upon or should give an equivalent thing.

The Charter included all the necessary elements of expropriation: that land and any building on it might be compulsorily taken by government, that this was to be done where it was deemed necessary in the interest of public, that the owner would be compensated based on the assessment of experts, and that the compensation would be made either in money or in kind. The Charter was influenced by the French Civil Code (Code Napoleon) since the last clause of the charter referred us to "Code Napoleon in the event this edict is not sufficiently covering other different issues." In any case, what we gather from the reading of the expropriation provision of this decree is that expropriation procedure had to be done by the city municipality itself. Courts were unlikely to be involved either in deciding the existence of "public purpose" or fairness of compensation since nothing has been said about them. In the event of compensation assessment, "government experts" would assess the value of the land and the house thereon, if any. These experts were most likely urban engineers from the city municipality.

\section{3- Expropriation in Ethiopia, Post-1931}

\subsection{The 1931 Constitution and 1955 Revised Constitution}

Menelik's legislative initiative to safeguard private property was continued by his successors, mainly, by Emperor Haile Sellassie I, and "the crowning act in the process of reinforcing the security of rist-holders was the 1931 Constitution". "F5 the first time in the history of the country, a written constitution was adopted in 1931 which, among others, included protection accorded to private property. One constitutional provision (Article 27) was dedicated to the issue of expropriation to allow the sovereign to take land in case of public necessity.

Although unpublished with the Constitution itself, a supplement was added, of which Chapter Eight is of paramount importance. Chapter Eight of the supplement of the constitution contains three Articles (Arts.74-76) guaranteeing the inviolability of the property of the Emperor and the royal family, the princes, territorial governors and other Ethiopian citizens by banning, except in the event of ascertained public utility, expropriation of land as form of punishment for crime. ${ }^{56}$ For the sake historical reminder, we reproduce these articles as follows:

${ }^{55}$ Bahru Zewde, supra note 53, p. 106.

${ }^{56}$ The 1931 Ethiopian Constitution as reproduced in Paul and Clapham, cited supra note 23, pp. 326-336; see also Mahteme-Sellassie, cited supra note 48, p.771 \& 789; 
Article 27

Except in cases of public necessity determined by the law, no one shall have the right to deprive an Ethiopian subject of any movable or landed property which he owns.

\title{
Article 74
}

It is determined by law that land and property hitherto in the hands of the Emperor and of members of the Imperial family, and all lands which they may acquire in future by purchase like any ordinary citizens shall, subject to the observance of the established regulations concerning land, be confirmed to them and shall be heritable to their descendants

\section{Article 75}

It is determined by law that similarly princes and territorial governors and all other Ethiopian citizens, who commit any sort of crime, shall be punished according to the provisions of the law, but landed property which they have hitherto held, or which they may acquire in future by purchase, shall not be confiscated.

\begin{abstract}
Article 76
Nevertheless, if it is necessary for the Government to construct on another person's land installations for the public welfare, such as forts, roads, markets, churches, schools, hospitals, townships or any work of this kind, it is determined by law that if the Deliberative Chambers have declared it necessary, the land owner shall be given a fair price as determined by law, or, subject to the landowner's consent, he shall receive some other similar compensation, and he shall be compelled to surrender the property; but except in a case of this kind where the public welfare is involved, a person's land may not be taken from him with a view to benefiting an individual.
\end{abstract}

The main provision (Article 27) is brief and cannot tell whether it includes compensation. But the supplementary provision (Article 76) provides details and describes the former. Thus, where public welfare (purpose) requires, a privately owned land may be taken by government upon the declaration of parliament to that effect and payment of compensation as fixed by a different law.

What is interesting is that the Constitution, although written in the image of the Japanese Meiji Constitution, ${ }^{57}$ incorporates in its expropriation declaration

also it is found on some web pages, such as

http://www.worldstatesmen.org/Ethiopia_1931.txt

${ }^{57}$ Bahru Zewde (2008). The Concept of Japanization in the Intellectual History of Modern Ethiopia. In: Bahru Zewde (ed.) Society, State and History: Selected Essays., Addis Ababa University Press, Addis Ababa, p. 206; Marcus, H. G. (1994) A History of Ethiopia, University of California Press, Los Angeles, p. 134. 
an English type of requirement when it demands parliamentarian approval of the project before expropriating the land. ${ }^{58}$ The other important characteristic of this rule is that expropriation would not be made with the sole purpose of benefiting another individual. This rule by and large restricts the absolute prerogative of the sovereign powers of the king as well as territorial governors in interfering in the private holding or ownerships of individual citizens.

Although the constitution presumes that a different subsidiary legislation would be enacted pertaining to expropriation, this had not come to light during the lifetime of the constitution. Nevertheless, we have other decrees which incidentally mentioned it, such as the 1933 "Land Lease to Foreigners Decree" which under Article 8 reflects the principle enshrined in the constitution:

The Government shall have the right to take any land deemed necessary for market, churches, fortifications, railways, or other similar services upon payment of due compensation. ${ }^{59}$

Significant developments have been occurring in Ethiopia following the Italian occupation of Ethiopia from 1936-1941 during which Italy invested much in infrastructure construction of the country. The Italians constructed thousands of kilometers of roads, bridges, urban streets, town halls, government and court buildings in Ethiopia within the five years of their occupation. They had also a plan, the execution of which had actually been started, to settle Italian farmers in Ethiopia. To this end, land was expropriated from private individuals in urban and rural areas to implement the Italian colonial policy. In spite of its scantiness, there is evidence that the colonialists used to pay compensation, although not adequate. The Ethiopians were paid much less than the market value for their land. In Addis Ababa, for example, between 1937 and 1938, property worth about ten million Italian Lire was confiscated for colonization and new urban planning, but less than two million Lire was paid by way of compensation. ${ }^{60}$

On the contrary, it seems, the Italians profited by selling land, which was expropriated from the local people. In Addis Ababa, for example, land taken from Ethiopians was parceled out into small plots and sold at prices between 15 per cent and 60 per cent higher than the price of compensation. ${ }^{61}$ Large tracts of rural farm lands occupied by the Ethiopian state and private farmers were also confiscated to settle Italian farmers. The precise scale of such confiscations is

\footnotetext{
${ }^{58}$ In England only Parliament has authority to take a land by compulsory purchase. In modern times, this authority is delegated to few public organs in order to avoid repetitive laws enacted for such takings. For details, generally see Denyer-Green, B. (2009) Compulsory Purchase and Compensation, London, EG Book.

${ }^{59}$ Pankhurst:1966, supra note 23, p. 208.

${ }^{60}$ H. M. Larebo (1994). The Building of an Empire: Italian Land Policy in Ethiopia 1935-1941, Oxford, Clarendon Press, p. 245.

${ }^{61}$ Ibid.
} 
not easy to establish. Yet, cases suggest that the Italians, at an early stage, did not hesitate to take any land thought essential for the viability of settler farms. By the end of 1939, land given in this way to the settlers totaled 186,000 hectares, not including lands that were made part of the public domain but not yet allocated. ${ }^{62}$

After the expulsion of the Italian forces from Ethiopia in 1941, the Imperial regime of Haile Sellassie resumed office, and the old laws were restituted. The Italians neither declared nor left any legislation concerning land in Ethiopia. The 1931 Ethiopian Constitution rather had been operating for the next decade and half without any change. It was revised in 1955 and a new rule replaced the previous expropriation provisions. Although it was not as detailed as the former ones, Article 44 of the 1955 Revised Constitution embodied enough information regarding expropriation. It provided:

Everyone has the right, within the limits of the law, to own and dispose of property. No one may be deprived of his property except upon a finding by ministerial order issued pursuant to the requirements of a special expropriation law enacted ... and except upon payment of just compensation determined in the absence of agreement, by judicial procedures established by law... ${ }^{63}$

A detailed scrutiny of the rule reveals that unlike the 1931 Constitution, the revised one follows an American type of procedure by involving courts in the expropriation proceeding. ${ }^{64}$ The constitution anticipated the issuance of a detailed expropriation proclamation in the future that would establish all the procedures of expropriation presumably including its public interest aspect. The assumption of the constitution seems to have been that an agreement would be arrived on the amount between the landowner and the ministerial authority that renders the decision of the expropriation; and otherwise compensation would be determined by a court of law.

${ }^{62}$ Ibid.

${ }^{63}$ The Revised 1955 Constitution of Empire of Ethiopia: http://www.angelfire.com/ny/ethiocrown/Constitution.html

${ }^{64}$ The practice in the USA is that condemning organ such as city authorities tries to negotiate first with owners to acquire the land necessary for public use through purchase. If the owner refuses to sale the land, the authority initiates condemnation proceeding in court. The request is for the court to decide on the public use nature of the project and the amount of compensation to be paid. The judicial power of courts emanate generally from the fifth and fourteenth amendments of the US Constitution which deal with property right and due process of law respectively. 


\subsection{The 1960 Ethiopian Civil Code}

The constitutional principle embodied under Article 44 of the 1955 Revised Constitution which provides "everyone has the right, within the limits of the law, to own and dispose of property," was reproduced in detail in the 1960 Ethiopian Civil Code. The Civil Code allocated a substantial part of its section to property law in general and expropriation in particular. ${ }^{65}$ The Civil Code was drafted by the French Comparative Lawyer, René David, and one can see the major influence of the French Civil Code on the Ethiopian property law and by extension on the expropriation provisions. Like the Roman law tradition of continental Europe ${ }^{66}$ "ownership" is defined under the Ethiopian Civil Code as "the widest right that may be had on a corporeal thing," and "such right may neither be divided nor restricted except in accordance with the law." ${ }^{\circ 7}$ In the Roman law tradition, ownership is conceived as absolute ${ }^{68}$ except that it may be sometimes restricted where it is provided so by law. Expropriation is one example of those restrictions or interferences on ownership.

The Code recognizes "alignment" and "expropriation" as the two methods of land acquisition modalities. Expropriation is used for the "creation of new roads and streets" $" 69$ while alignment proceeding serves to "widen or straighten existing roads or streets." $"$ As already pointed out above, expropriation has not been properly defined in the Code; what is defined is "expropriation proceeding." The purposes of expropriation are generally gathered from two different provisions of the law. They are to "acquire land for public purposes,", and to "acquiring or extinguishing a rights of usufruct, servitude or other rights

${ }^{65}$ Of the Civil Code, Book III, Titles VI-X are allocated for property. In particular, under Title IX, Arts. 1460-1488 are dedicated to expropriation.

${ }^{66}$ Article 544 of French Civil Code reads: "Ownership is the right to enjoy and dispose of things in the most absolute manner provided that they are not used in a way prohibited by statute or regulations." The Code is available at http://195.83.177.9/upl/pdf/code 22.pdf

${ }^{67}$ Article 1204 (1) \& (2) of Ethiopian Civil Code.

${ }^{68}$ In the Roman law tradition ownership right is conceived as absolute. Although difficult to define, it connotes, among others, that ownership is the greatest right that a person can have on property, that it is inherently unrestricted and that it is the only right of its kind, that there is no lesser form of ownership. For details see Simpson, S. R. (1961). Towards a Definition of "Absolute Ownership": II. Journal of African Law, 5, 145-151; Birks, P. (1985). The Roman Law Concept of Dominium and the Idea of Absolute Ownership. Acta Juridica, 28.; Pierre, B. (1997). Classification of Property and Conceptions of Ownership in Civil and Common Law. Revue Generale De Droit, 28, 235-274.

${ }^{69}$ Ethiopian Civil Code, Article 1450(1).

${ }^{70}$ Id., Article 1450(2).

${ }^{71}$ Id., Article 1460. 
in rem",72 and to "terminate" any "prior lease contract" Before resorting to the expropriation proceeding, the competent authority shall first declare the intended project is for public purpose and notify the owner of the land thereof; and where a public discussion appears to be necessary, the condemning authority shall consult the public before declaration of public purpose. $^{74}$

What constitutes public purpose has not been clearly envisaged in a manner such as what we saw above under the 1931 Ethiopian Constitution. But, the Code gives a clue by stating that expropriation may be used "to enable the public to benefit by the increase in the value of land arising from works done in the public interest." ${ }^{, 75}$ What we can assume is that roads and streets may increase the value of adjacent properties and this is what the law intends to say. On the other hand, expropriation proceeding may not be used for the sole purpose of obtaining financial benefits. ${ }^{76}$ Concerning compensation, it has been said under Article 1474 that "the amount of compensation or the value of the land that may be given to replace the expropriated land shall be equal to the amount of the actual damage caused by expropriation;" and this compensation shall be one "which is assessed by the committee on the day when it makes its decision." Even if it can be said that the amount is fair compared to, for example today's compensation, it cannot be said that it is equal to market price. ${ }^{77}$

\subsection{Expropriation in Post 1975 Ethiopia}

The Civil Code expropriation provisions were partially suspended following the demise of the Imperial regime and the assumption of power by the Marxist Military Derg ${ }^{78}$ regime which nationalized all rural ${ }^{79}$ and urban lands and urban extra houses ${ }^{80}$ and abolished private ownership of land. The very idea of sanctity of private property and the need to use expropriation under exceptional cases of "public interest" was defeated by the very nationalization act of the military

\footnotetext{
${ }^{72}$ Id., Article 1461(1).

${ }^{73}$ Id., Article 1461(2).

${ }^{74}$ See Articles 1463-1465.

${ }^{75}$ Id., Article 1464(2).

${ }^{76}$ Id., Article 1464(1).

${ }^{77}$ See for example, Daniel: 2013b, supra note 2; Also presented and published at FIG Conference, Kuala Lumpur, Malaysia, p. 17-18. http://www.fig.net/pub/fig2014/papers/ts01f/TS01F_ambaye_6821.pdf

${ }^{78}$ Daniel W. Ambaye. (2012) Land Rights in Ethiopia: ownership, equity and liberty in land use, FIG Conference paper, Rome. http://www.fig.net/pub/fig2012/papers/ts02d/TS02D_ambaye_5521.pdf

${ }^{79}$ Public Ownership of Rural Lands, Proclamation No. 31/1975. Negarit Gazeta. Year 34, No. 26.

${ }^{80}$ Government Ownership of Urban Land and Extra Houses, Proclamation No. 47/1975. Negarit Gazeta : Year 34, No. 41.
} 
government. What makes nationalization different from expropriation is that the former is devoid of any compensation.

Rather, without mentioning the status of the Civil Code expropriation rules, the Derg inserted its own expropriation rules in its rural and urban land proclamations. The 1975 Rural Land Proclamation ${ }^{81}$ embodied Article 17 (Power of Expropriation) which provides the following:

1) The Government may use land belonging to peasant associations for public purposes such as schools, hospitals, roads, offices, military bases and agricultural projects.

2) The Government shall make good such damage as it may cause the peasant association by decision to expropriate the holding.

Likewise, Proclamation 47/1975 provided the following regarding urban land:

Article 8: Power of Taking and Expropriation

1) Where a person, family or organization fails to utilize his or its urban land within the period to be specified by the Ministry, the Ministry may take back such land and put it to appropriate use.

2) The ministry shall, by giving compensation in kind, expropriate for public purpose urban land held by person, family or an organization.

Article 19: Expropriation of Houses

The Government may, by paying compensation, expropriate for public purpose an urban house held by any person, family or organization.

What is clear is that in the event of expropriation of urban and rural land, the compensation is to be made in kind, that is land to land. Since land was owned by the state, it is obvious, that the location of replacement land was of little consequence. It means, since land had no value, a change in location would not bring about a change in compensation amount.

It is unique to the rural land proclamation that it adopted a restricted approach to public purpose definition by confining it to the classical state activities such as roads, school, and military camps. Unlike the Civil Code, which is silent in this respect, Proc. No. 31/1975 follows the approach of the 1931 Constitution. This has not been, however, repeated in the urban land law Proc. 47/1975.

With regard to the expropriation of urban houses, Proclamation No. 47/1975 states that compensation would be paid. However, it does not bother to show the modality of property assessment. Whether it should be valued based on market value of the property or as cost replacement is not known. But in the absence of such rules, the assumption is that courts would use the Civil Code as reference.

${ }^{81}$ Supra note 79. 
After the fall of the Derg and its replacement by the transitional government, there was no significant legal development concerning land expropriation except the 1993 urban land lease proclamation which incidentally mentions expropriation as a means to terminate lease contract ${ }^{82}$ and the possibility of payment of compensation in such situation. ${ }^{83}$ This approach was never changed in the subsequent lease Proclamation No. 272/2002 as well.

However, there was a change in the definition given for "public interest" and a new concept, "Clearance of Urban Land," was introduced representing the idea of expropriation. ${ }^{84}$ The practice looks like what is known as "resumption" instead of expropriation. Resumption refers to the reclaiming of government land provided by lease contract upon reimbursement of a paid up lease price.

Significant change was introduced in respect of land ownership in general and expropriation in particular in 1995, following the adoption of the FDRE Constitution. The FDRE Constitution recognizes ownership right of private property in Ethiopia. ${ }^{85}$ The definition of private property, however, excludes land as a subject of private property; its ownership is vested in the state and the people. ${ }^{86}$ The constitution guarantees the right of owning and disposal of any property established on the land. It also guarantees this right by providing commensurate amount of compensation in the event of expropriation of private property for public purpose activities. ${ }^{87}$ The difficulty in this regard is that there seems to be an apparent contradiction between Art. 40(3) of the Constitution that guarantees joint ownership of land by the people and the state and Art. $40(8)$, that denies compensation for the loss of land by expropriation. ${ }^{88}$

There was a time gap for the next ten years and attempt was made in 2004 to promulgate a new expropriation proclamation (Proclamation 401/2004). ${ }^{89}$ This proclamation was brief and contained only sixteen provisions. Most of its contents are included in the present Expropriation Proclamation No. 455/2005, ${ }^{90}$ the content of which is beyond the scope of this article. The significant characteristic of Proclamation No. 401/2004 was that unlike the Civil Code or

${ }^{82}$ Proclamation to Provide for the Lease Holding of Urban Land, Negarit Gazeta, Year 53, No. 40. Art.11 (1) (b).

${ }^{83}$ Id., Art. 11(3).

${ }^{84}$ See Articles Re-enactment of Urban Land Lease Holding Proclamation No. 272/2002, Negarit Gazeta, Year 8, No. 19, Art. 16.

${ }^{85}$ FDRE Constitution Art. 40(1).

${ }_{87}^{86}$ Id., Art. 40(3).

${ }^{87}$ Id., Art. 40(8).

${ }^{88}$ For detail on this argument, see Daniel: 2013a, supra note 2.

${ }^{89}$ Appropriation of Land for Government Works and Payment of Compensation for Property Proclamation No. 401/2004.

${ }^{90}$ Expropriation of Landholdings for Public Purposes and Payment of Compensation Proclamation No. 455/2005. 
the current expropriation legislation listed down the type of activities that should be considered as works carried out in the public interest. The list under Article 2 included such activities as power generating plants, highways, airports, dams, railways, fuel depots, water and sewerage facilities, telephone and electrical works and other related activities. In this way, one can notice that the legislation had followed its predecessors by adopting a narrower concept of public purpose.

\section{Conclusion}

Expropriation is a forced taking of land by the state from private owners for public purpose activities and against payment of adequate compensation. What makes expropriation different from nationalization and confiscation is that the latter two are devoid of compensation. Looking into the Ethiopia's past, one may realize that these three measures, i.e. expropriation, nationalization and confiscation were implemented by monarchs and governments.

Even if confiscation might be predominant, considering the absolute power of the sovereigns of different ages, we prefer to argue here that there were also incidents of expropriation cases where the expropriating organ was paying compensation in kind or cash. Yet, lack of historical records about expropriation prevents us from being conclusive about its practice, which requires further research in the area.

However, expropriation saw continuous and recorded development since the reign of Emperor Menelik II in general and the promulgation of the 1908 Addis Ababa Land Charter in particular. The 1931 and 1955 Constitutions of the imperial era provided adequate protection to private property by exceptionally allowing expropriation measure only for public purpose activities. This protection was also given emphasis in the 1960 Ethiopian Civil Code which addressed expropriation adequately. Under the Civil Code expropriation was allowed only under strict public purpose cases, and in effect, it, for example, did not allow expropriation of land for pure financial gains that can be obtained from the reallocation of land to investment. However, the protection provided by the Civil Code to private property was sidelined after the nationalization of all land by the Derg in 1975.

As the nationalization of rural and urban land in 1975 was confiscation and not expropriation, the legal regime that defined 'public purpose' in its traditional context of public works such as roads, public utilities, etc. was not formally changed until Proclamation No. 455/2005 and others widened the definition of 'public purpose'. While the notion of public ownership of land has been inherited by the current Constitution and other laws which deny economic value for land upon expropriation, the laws that changed the Civil Code's definition of 'public purpose' have widened the grounds for expropriation. 